\title{
Study of Nutritional Status of Tribal \& Non Tribal Marginal Farm Women
}

\author{
Manisha Choudhary ${ }^{1}$, Aruna Palta ${ }^{2}$, Abhaya Joglekar ${ }^{3}$ \\ ${ }^{1}$ Research Scholar and Subject Matter Specialist, KVK, Raigarh, Chhattisgarh, India \\ ${ }^{2}$ Principal, Dr, Radha Bai Govt Naveen Girls College, Raipur, Chhattisgarh, India \\ ${ }^{3}$ Professor of Home Science, Govt. D. B. P. G. College, Raipur, Chhattisgarh, India
}

\begin{abstract}
The present study was carried out on300 marginal farm women of Raigarh district of Chhattisgarh State in India. The district comprises of 9 blocks, out of which two tribal and two non tribal blocks were selected for the study. The marginal farm women aged 18-45 years were selected by purposive random sampling method. The data were collected with the help of self developed, pretested questionnaire. Height and weight of the subjects was taken using standard technique. Body Mass Index (BMI) was calculated from height and weight measurement. The study revealed that there was no significant difference between average heights of both tribal and non tribal women but as far as weight and BMI is concerned; the figures were higher for non-tribal farm women than their tribal counterparts. It was also concluded that both the groups of farm women had lower weights and heights when compared to recommendations of Indian Council of Medical Research. (55 $\mathrm{kg}$ as average body weight and 151 cm as average height.)
\end{abstract}

Keywords: Nutritional Status, measurements, Farm women, Tribal women, Non tribal women Anthropometric

\section{Introduction}

The rural women constitute an overwhelming majority of women in developing countries. In Raigarh district half of the female population lives in rural areas (Census, 2011). The farm Women play multiple roles in a family, primarily as mothers \&housekeepers. They also play equally important roles as agricultural producers, wage earners, nutrition providers etc.

The Farm women are the backbone of agricultural work force, however worldwide their hard work has mostly been unpaid. They do the most tedious and back-breaking tasks in agriculture, animal husbandry besides the domestic chores. Agriculture is the largest industry in India and the women participate in almost all agricultural operations such as transplanting, weeding, threshing, winnowing, harvesting, etc. The involvement of women in agriculture sector is not a new phenomenon and they have been recognized as the backbone of Indian agriculture since its beginning.

Agriculture has always been India's most important economic sector. Overall $60 \%$ of Indian population engages in agriculture as their main source of income. Agriculture in country like India needs lot of man power. If the total manpower is split as per gender, it gives amazing fact that, the women contribution is greater or equal to men. Nearly 63 percent of all economically active men are engaged in agriculture, as compared to 78 per cent of women. About 70 percent of farm work is performed by women. (E. Krishna Rao, 2006)

Raigarh is one of the most important potential district of Chhattisgarh in terms of area, production and productivity of different crops. The Tribal population is $35.38 \%$ of the total population. Tribal women can be considered as weaker section of the society, especially women who have lagged behind in all agriculture fields. They are an essential part of our civilization, yet they mark clear difference from the main stream population in terms of resisting change.

Several research studies on tribal population of India revealed that prevalence of chronic energy deficiency was high among tribal population. The Women being in vulnerable group, the impact on their health is much higher. The health \& nutritional status of tribal \& non tribal farm women population clearly indicates that the goal of health for farm women cannot be fully achieved unless due attention is being paid on improving their status of nutrition. Based on this background, this study was conducted in the tribal \& non tribal marginal farm women of Raigarh District of Chhattisgarh to assess the nutritional status of farm women.

\section{Literature Survey}

Srivastava \& Singh (2014) observed a case study understanding Nutritional situation of farm women in rural arid area of Rajasthan. Nutritional status was assessed using BMI based classification proposed by WHO 2004. The observations indicated that young females between 18-30 years age group were most affected while the extent of under nutrition was comparatively lesser in the elderly group.

Rao et al. (2010) conducted a wide spread study in nine states of India to see the nutritional status of rural and tribal population.

The study revealed inadequate dietary intake, especially micronutrient deficiency (hidden hunger) during pregnancy and lactation. The prevalence of goiter was relatively higher $(4.9 \%)$ among tribal women compared to their rural counterparts $(0.8 \%)$. Tribal women were particularly vulnerable to under nutrition compared to women in rural areas. The prevalence of chronic energy deficiency was higher (56\%) among tribal NPNL women compared to rural women $(36 \%)$. 


\section{International Journal of Science and Research (IJSR) \\ ISSN (Online): 2319-7064 \\ Index Copernicus Value (2016): 79.57 | Impact Factor (2015): 6.391}

\section{Materials \& Method}

This is a descriptive cross sectional study with a survey performed on nutritional profile of tribal and non tribal marginal farm women at Raigarh District of Chhattisgarh. The study was carried out on 300 tribal and non tribal farm women to assess their nutritional status with 150 women in each tribal \& non tribal category. The district comprises of 9 blocks out of which two tribal and two non tribal blocks were selected for the study. Total 300 marginal farm women between age group 18-45 years available at home at the time of study and who were willing to participate were selected for this study. Pregnant\& lactating farm women and women with chronic infectious diseases were excluded from this study. All the selected samples were divided into two groups: tribal and non tribal, comprising of farm women either working in farm or involved in other agricultural activities. Data was collected with the help of close ended and open ended questionnaires. The data was analyzed statistically by applying different suitable tests to compare between the two groups and to find out the significant difference between them. Anthropometric measurements such as height $\&$ weight were measured and Body mass index were calculated. According to the WHO classification of BMI, the subjects were categorized as underweight $(<18.50)$, Normal (18.50-25) and overweight $(>25)$. Chi-square test was used to test the significance of results.

\section{Results \& Discussion}

Table 1: Comparison of Body Mass Index (BMI) of Tribal and Non Tribal Marginal Farm Women

\begin{tabular}{|c|c|c|c|c|c|c|}
\hline \multirow{2}{*}{$\begin{array}{c}\text { BMI (kg/m } \\
\text { Categories }\end{array}$} & \multicolumn{2}{|c|}{$\begin{array}{c}\text { Tribal } \\
\text { Marginal } \\
\text { Farm } \\
\text { Women }\end{array}$} & $\begin{array}{c}\text { Non-Tribal } \\
\text { Marginal } \\
\text { Farm } \\
\text { Women }\end{array}$ & \multicolumn{2}{|c|}{ Total } \\
\cline { 2 - 7 } & No. & \% & No. & $\%$ & No. & $\%$ \\
\hline $\begin{array}{c}\text { Underweight } \\
<18.5\end{array}$ & 50 & 33.3 & 32 & 21.3 & 82 & 27.3 \\
\hline Normal 18.5-25 & 96 & 64.0 & 110 & 73.4 & 206 & 68.7 \\
\hline $\begin{array}{c}\text { Overweight 25- } \\
30\end{array}$ & 04 & 2.7 & 08 & 5.3 & 12 & 4.0 \\
\hline Total & 150 & 100 & 150 & 100 & 300 & 100 \\
\hline
\end{tabular}

$\chi 2(\mathrm{df}=2)=6.44, \mathrm{p}<0.05$

- Tribal Farmwomen Non Tribal women

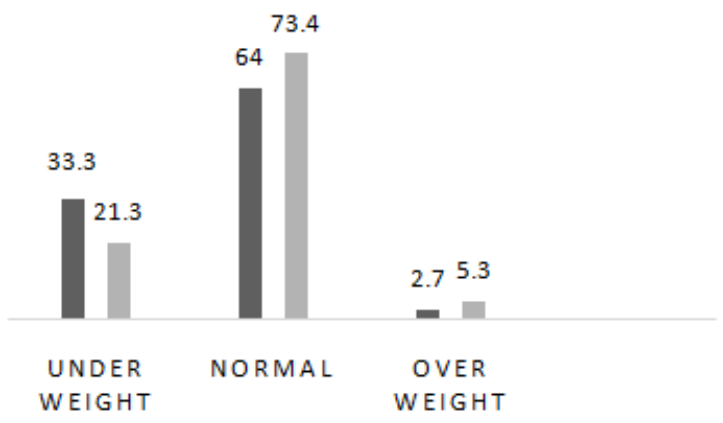

Perusal of entries reported in table 1 gives following inferences:
- Percentage of non-tribal marginal farm women with normal BMI was higher $(73.4 \%)$ as compared to tribal marginal farm women.

- $2.7 \%$ tribal marginal farm women were overweight while $5.3 \%$ non tribal marginal farm women were placed in overweight category.

- 33\% tribal marginal farm women were underweight while $21.3 \%$ non tribal marginal farm women were placed in underweight category.

Results indicate that non-tribal marginal farm women revealed better nutritional status as compared to tribal marginal farm women. The calculated $\chi^{2}(\mathrm{df}=2)=6.44$, $\mathrm{p}<.05$ also shows that nutritional status of farm women was significantly influenced by their tribal and non-tribal origin.

The frequency distribution of tribal and non-tribal marginal farm women between ages of 18 to 30 years as per Body mass index is shown in table 2.

Table 2: Comparison of BMI of Tribal and Non Tribal Marginal Farm Women (18 to 30 years)

\begin{tabular}{|c|c|c|c|c|c|c|}
\hline \multirow{2}{*}{$\begin{array}{c}\text { BMI } \\
\text { Categories }\end{array}$} & \multicolumn{2}{|c|}{$\begin{array}{c}\text { Tribal } \\
\text { Marginal } \\
\text { Farm } \\
\text { Women }\end{array}$} & \multicolumn{2}{|c|}{$\begin{array}{c}\text { Non-Tribal } \\
\text { Marginal } \\
\text { Farm } \\
\text { Women }\end{array}$} & \multicolumn{2}{|c|}{ Total } \\
\cline { 2 - 7 } & No. & $\%$ & No. & $\%$ & No. & $\%$ \\
\hline $\begin{array}{c}\text { Underweight } \\
<18.5\end{array}$ & 18 & 26.5 & 14 & 36.8 & 32 & 30.2 \\
\hline Normal 18.5-25 & 50 & 73.5 & 22 & 57.9 & 72 & 67.9 \\
\hline $\begin{array}{c}\text { Overweight 25- } \\
30\end{array}$ & 00 & 00 & 02 & 5.3 & 02 & 1.9 \\
\hline Total & 68 & 100 & 38 & 100 & 106 & 100 \\
\hline
\end{tabular}

$\chi^{2}(\mathrm{df}=2)=5.32, \mathrm{p}>0.05$

Tribal Farm Women $\square$ Non-Tribal Farm Women

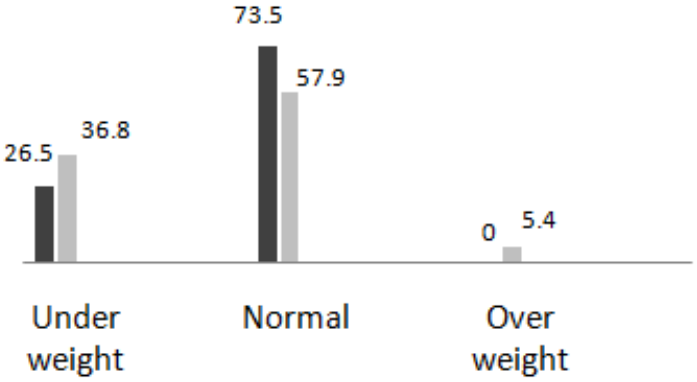

Perusal of entries reported in table 2 gives following inferences:

- $26.5 \%$ tribal marginal farm women were underweight while $36.8 \%$ non-tribal marginal farm women were placed in underweight category.

- Percentage of tribal marginal farm women with normal BMI was higher $(73.5 \%)$ as compared to non-tribal marginal farm women $(57.9 \%)$.

- $5.3 \%$ non-tribal marginal farm women were overweight while none from tribal marginal farm women were placed in overweight category. 


\section{International Journal of Science and Research (IJSR) \\ ISSN (Online): 2319-7064}

Index Copernicus Value (2016): 79.57 | Impact Factor (2015): 6.391

Results indicate that tribal marginal farm women revealed better nutritional status as compared to non-tribal marginal farm women but this fact could not be verified statistically.

Frequency distribution of tribal and non-tribal marginal farm women between 30 to 45 years of age as per Body mass index is shown in table 3 .

Table 3: Comparison of BMI (Body Mass Index) of Tribal and Non Tribal Marginal Farm Women ( 30-45 years).

\begin{tabular}{|c|c|c|c|c|c|c|}
\hline \multirow{2}{*}{$\begin{array}{c}\text { BMI } \\
\text { Categories }\end{array}$} & \multicolumn{2}{|c|}{$\begin{array}{c}\text { Tribal } \\
\text { Marginal } \\
\text { Farm } \\
\text { Women }\end{array}$} & \multicolumn{2}{|c|}{$\begin{array}{c}\text { Non-Tribal } \\
\text { Marginal } \\
\text { Farm } \\
\text { Women }\end{array}$} & \multicolumn{2}{|c|}{ Total } \\
\cline { 2 - 7 } & No. & $\%$ & No. & $\%$ & No. & $\%$ \\
\hline $\begin{array}{c}\text { Underweight } \\
<18.5\end{array}$ & 32 & 39.0 & 18 & 16.1 & 50 & 25.8 \\
\hline Normal 18.5-25 & 46 & 56.1 & 88 & 78.6 & 134 & 69.1 \\
\hline $\begin{array}{c}\text { Overweight 25- } \\
30\end{array}$ & 04 & 4.9 & 06 & 5.4 & 10 & 5.2 \\
\hline Total & 82 & 100 & 112 & 100 & 194 & 100 \\
\hline
\end{tabular}

$\chi 2(\mathrm{df}=2)=13.16, \mathrm{p}<0.01$

- Tribal Farm Women non-Tribal Farm Women

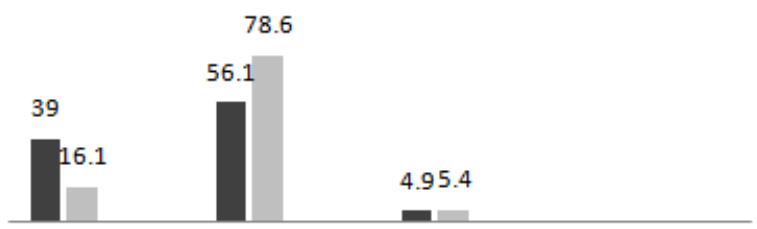

Under Normal Overweight

weight

Perusal of entries reported in table 3 gives following inferences:

- 39\% tribal marginal farm women were underweight while $16.1 \%$ non tribal marginal farm women were placed in underweight category.

- Percentage of non-tribal marginal farm women with normal BMI was higher $(78.6 \%)$ as compared to tribal marginal farm women $(56.1 \%)$.

- $4.9 \%$ tribal marginal farm women were overweight while $5.4 \%$ non tribal marginal farm women were placed in overweight category.

Results indicate that non-tribal marginal farm women revealed significantly better nutritional status as compared to tribal marginal farm women. The calculated $\chi 2(\mathrm{df}=2)=$ $13.16, \mathrm{p}<.01$ also indicated that nutritional status of farm women was significantly influenced by their tribal and non-tribal origin.

\section{Summary}

The findings of the present study clearly indicated that non tribal farm women had comparatively better weight than tribal farm women but in both the cases it is less than recommendation of ICMR which is $55 \mathrm{~kg}$ for Indian reference women. This finding that Non tribal women have better nutritional status than tribal women is supported by the study of Rao et al. (2010) who also reported that tribal women were particularly vulnerable to under nutrition as compared to other women living in villages.

From the above study it can also be concluded that younger tribal farm women in age group of 18-30 years were having low BMI as compared to those in age group of 31-45 years. Similar findings were observed by Srivastava \& Singh (2014).

\section{Acknowledgement}

The authors would like to thank all the tribal and non tribal farm women as well as their families for their cooperation.

\section{References}

[1] Nayak, M. Siva Durga Prasad \& Sreegiri, Sunita (2016) A study on nutritional status of tribal women in Visakhapatnam district, Andhra Pradesh, India. International Journal of community Medicine and public health, Aug: 3(8):2049-2053.

[2] Rao, K. Mallikharjuna, Balakrishna, N., Arlappa, N., Laxmaiah A. \& Brahmam G.N.V. (2010) Diet and nutritional status of women in India. Journal of Human Ecology, 29, 3, 165-170.

[3] Srivastava, S. \& Singh, B. (2014) Understanding nutritional situation of farm women in rural arid area of Rajasthan's case study. Journal of agriculture science and life sciences.vol 1, No.2, ISSN 23754222.

[4] Mishra, D. \& Singh, R.(2015). A study on energy balance of farm women. Acta scientific international journal of food and nutrition, vol 1, Issue1, 8-15.

[5] Rao, K. Mallikharjuna, Balakrishna, N., Arlappa, N., Laxmaiah A. \& Brahmam G.N.V. (2010). Diet and nutritional status of women in India. Journal of Human Ecology, 29(3):165-170.

[6] Bellurkar, M,Chitra (2015).Daily food intake and nutrient intake by the farm women. International Journal of Scientific and Research Publications, Volume 5, Issue 11, ISSN 2250-3153.

[7] Gole Uma (2015).Nutritional status of the Oraon tribes of Jashpur district, Chhattisgarh. International Journal of Scientific and Research Publications, Volume 5, Issue 11, ISSN 2250-3153.

\section{Authors Profile}

Manisha Choudhary, is Research Scholar and Subject Matter Specialist, KVK, Raigarh, Chhattisgarh, India.

Aruna Palta, Principal at Dr, Radha Bai Govt Naveen Girls College, Raipur, Chhattisgarh, India is .in the field of Nutrition for the past 36 years, published 63 Research papers, 17 Books and Guided 20 Ph.Ds.

Abhaya Joglekar is Professor of Home Science, Govt. D. B. P. G. College, Raipur, Chhattisgarh, India

\section{Volume 6 Issue 12, December 2017}

